\title{
An Anthropocentric Evaluation of the New English Language Teaching Program for Lower Secondary School in Turkey
}

\author{
Ahmet Erdost Yastıbaș* \\ Received: March 26, 2020; received in revised form: April 26, 2020; \\ accepted: April 28, 2020
}

\begin{abstract}
:
Introduction: The earth has entered a new geological epoch: the Anthropocene. The Anthropocene demonstrates how human activities have changed the world negatively by causing several environmental issues such as global warming. Therefore, it has become an important problem for people. Education should be reconsidered according to the new epoch to deal with it. There is a trans-disciplinary call for this issue. In relation to this call, the present study has aimed to evaluate the new English language teaching program (ELTP) for lower secondary school (5th, 6th, 7th, and 8th grades) in terms of the Anthropocene in Turkey.

Methods: The present study was designed as a qualitative study. The data collection tools were the new ELTP for lower secondary school and the 5th, 6th, 7th, and 8th-grade English language course books prepared according to the new program. The data were analyzed through documentation analysis. Triangulation and thick descriptions were used to make the study trustworthy.

Results: The documentation analysis of the data has showed that there are six themes related to the nature in the new ELTP for lower secondary school: theme 9 (the animal shelter) in the 5th grade; themes 4 (weather and emotions) and 9 (saving the planet) in the 6th grade; themes 4 (wild animals) and 9 (environment) in the 7th grade; theme 10 (natural forces) in the 8 th grade. The learning outcomes and language skills of each theme were prepared according to the contents of the themes. Theme 9 in the 5 th grade shows how human activities can affect the environment positively. Theme 4 in the 6 th grade indicates how the environment can affect people. The rest demonstrate how human activities have affected the nature negatively and how people can save the nature.

Discussion: Theme 9 (saving the planet) in the 6th grade, themes 4 (wild animals) and 9 (environment) in the 7th grade, and theme 10 (natural forces) in the 8th grade explain how several environmental issues have occurred owing to human activities, how these issues have affected the
\end{abstract}

\footnotetext{
* Ahmet Erdost Yastıbaș, Atilim University, School of Foreign Languages, Ankara, Turkey; ahmet.yastibas@atilim.edu.tr
} 


\title{
Acta Educationis Generalis \\ Volume 10, 2020, Issue 3
}

\begin{abstract}
nature and human lives negatively, and how people can deal with these issues. Theme 9 (the animal shelter) in the 5 th grade informs students about how human activities can affect the nature positively, and theme 4 (weather and emotions) in the 6th grade about how the environment can affect people. Through these themes, the new ELTP for lower secondary school can enable English language students to understand that people are a part of the nature, have the power to change the environment, and can live with the environment in balance.

Limitations: The curriculum evaluation is only related to the new ELTP for lower secondary school (5th, 6th, 7th, and 8th grades) in Turkey.

Conclusion: The Anthropocentric evaluation of the new ELTP for lower secondary school has shown that it can raise English language students' awareness of the relationship between people and the nature and their effects on each other.
\end{abstract}

Key words: the Anthropocene, the new English language teaching program, lower secondary school, curriculum evaluation.

\section{Introduction}

There are different geological epochs in the geological history of the world. The latest epoch following the Holocene is the Anthropocene. The Anthropocene plays a significant role in the future of the world because according to Crutzen (2006a, 2006b), Lewis and Maslin (2015), Steffen, Grinevald, Crutzen, and McNeill (2013), and Zalasiewicz, Williams, Haywood, and Ellis (2011), this new epoch indicates that people have become the only force on the world that changed, is changing, and will continue to change the environment deeply and negatively. The Anthropocene is closely related to human activities which directly affect the environment. Human activities result from overpopulation (Crutzen, 2006a, 2006b; Steffen et al., 2013; Zalasiewicz, Williams, Steffen, \& Crutzen, 2010) and the accompanying increasing need for food, water, and better life conditions (Crutzen, 2006a, 2006b). Such human activities include deforestation (Crutzen, 2006a, 2006b; Lewis \& Maslin, 2015; Steffen et al., 2013; Zalasiewicz et al., 2011), excessive use of water resources (Crutzen, 2006a, 2006b; Steffen et al., 2013), increasing amount of carbon dioxide (Crutzen, 2006a, 2006b; Steffen et al., 2013; Zalasiewicz et al., 2010; Zalasiewicz et al., 2011) and other greenhouse gases (Crutzen, 2006a), global warming (Crutzen, 2006a, 2006b; Lewis \& Maslin, 2015; Steffen et al., 2013; Zalasiewicz et al., 2010), the hole in the ozone layer (Crutzen, 2006a, 2006b; Lewis \& Maslin, 2015; Steffen et al., 2013), and the amount of nitrogen in water and land (Crutzen, 2006b; Lewis \& Maslin, 2015; Steffen et al., 2013). All of these activities have resulted in polluting the environment which has reduced biodiversity and caused many animal, insect, and plant species to become extinct (Crutzen, 2006a, 2006b). Therefore, the effects of human activities on the world 


\section{Acta Educationis Generalis \\ Volume 10, 2020, Issue 3}

are so huge that natural forces cannot compete with human activities in shaping the world (Steffen et al., 2013).

The effects of human activities on the environment have made the Anthropocene the most important problem to deal with for people as Zalasiewicz et al. (2011) emphasized. Dealing with the Anthropocene is vital to the sustainability of the environment for the future (Crutzen, 2006b). Therefore, it has led to an urgency for people to deal with it. People can deal with this urgency in some ways, one of which is education.

Dealing with the Anthropocene requires the reconsideration of education which makes the relationship between people and the world its center so that students can learn, understand, and realize that people are a part of the nature (Somerville, 2017). She mentioned that such education is based on the interaction between the human world and the more-than-human world which can be defined as other living and nonliving things in the environment. According to her, it aims to enable students to understand the essence of human existence (what makes humans is the more-than-human world) and the dependency of humans on the more-than-human world, therefore, in addition, it can help students to develop an understanding of how people can live in balance with the non-human (Somerville, 2017; Taylor, 2017). According to Sterling (2017), such education with these features can indicate students how human activities in nature can affect the environment and human lives negatively. He also added that this awareness raising can cause students to understand that people can live with the environment in balance (Sterling, 2017).

The call for trans-disciplinary education is necessary for the reconsideration of education considering the Anthropocene (Carstens, 2016; Leinfelder, 2013; Somerville, 2017). Therefore, including the Anthropocene in the curriculum of different disciplines has been suggested by different scholars: geography education by Pawson (2015), chemistry education by Mahaffy (2014), and science education by Gray and Colluci-Gray (2014), Gilbert (2016), and Wagler (2011). This can help students be aware of the relationship between human beings and non-human beings and their effects on each other, so they can learn how to live with the world in balance (Sterling, 2017).

English language teaching can also enable English language (EL) students to be aware of the Anthropocene and behave accordingly to live well with nature and contribute to a sustainable future. For this purpose, it should have and adopt an ecological attitude toward teaching English. The first way to achieve this goal is including the Anthropocene or topics related to it in the curriculum. Yet, the literature review has showed that several studies have been conducted to evaluate the English language teaching curricula for lower secondary school (also known as middle school) prepared at different times in Turkey (Aksoy, 2020; Aktı Aslan \& İzci, 2017; Arı, 2013; Demirtaş \& Erdem, 2015; Dinçer \& Koç, 2020; Dinçer \& Saracalıŏlu, 2017; Kozikoğlu, 2014; Ordem \& Ulum, 2020). These studies have generally focused on EL teachers' and students' ideas 


\section{Acta Educationis Generalis \\ Volume 10, 2020, Issue 3}

about the curriculum and have shown that the evaluated curricula have some strengths but need to be improved. These studies have not evaluated the curricula Anthropocentrically. In addition, two studies were found in the international literature related to language teaching when the present study was made. Goulah (2018) discussed the place of religion in language teaching in the Anthropocene, and Prádanos (2015) indicated that Spanish language course books had little ecological value. Therefore, the present study has aimed at evaluating the part of the new English language teaching program (ELTP) related to lower secondary school that was prepared in 2018 by the Ministry of National Education. Accordingly, it has focused on the research questions below:

1. Does the new ELTP for lower secondary school have any theme related to nature?

2. What are the students supposed to achieve in the nature-related theme(s) according to the new ELTP for lower secondary school as language skills and learning objectives?

3. How do the English language course books of the 5th, 6th, 7th, and 8th grades prepared according to the new ELTP for lower secondary school contextualize and practice the theme(s)?

\section{Methodology}

\subsection{Research design}

Through qualitative research, researchers can explore a social or human issue by understanding and having the meanings ascribed to it, so it provides a complex and detailed understanding of it (Creswell, 2014; Creswell \& Poth, 2018). As stated in the introduction, the Anthropocene affects human life and the environment negatively and deeply, so its negative effects make it a problem for human beings. In relation to this problem, the present study aimed to evaluate the part of the new ELTP for lower secondary schools in terms of how it deals with what the Anthropocene has showed people. Thus, it was designed as a qualitative study to provide a complex understanding of it in detail.

\subsection{Research context}

English is the most commonly taught foreign language in Turkey. The Ministry of National Education (MNE) prepares two centralized ELTPs for basic education and secondary education. In Turkey, basic education is composed of two steps: a) primary school (from 1st grade to 4th grade); and b) lower secondary school or middle school (from 5th grade to 8th grade). Secondary education is related to high school (from 9th grade to 12th grade). The centralized programs are followed to teach English by private and public primary, lower secondary, and high schools in Turkey. The curricula are prepared according to the levels of the Common European Framework of 


\section{Acta Educationis Generalis \\ Volume 10, 2020, Issue 3}

Reference for Languages (CEFR). According to the part of the ELTP for lower secondary school, the 5th and 6th-grade syllabi are aligned with the A1 level of the CEFR, while the 7th and 8th-grade syllabi are aligned with the A2 level of the CEFR. English language course books are prepared by the Turkish authors according to the ELTPs under the supervision of the MNE and are used to teach English in both private and public primary, lower secondary, and high schools in Turkey.

\subsection{Data collection tools}

Five documents were used to collect data.

1. İngilizce Dersi Öğretim Programı (İlkokul ve Ortaokul 1, 2, 3, 4, 5, 6, 7 ve 8. Sinıflar) [English Language Teaching Program (Primary School and Lower Secondary School 1st, 2nd, 3rd, 4th, 5th, 6th, 7th and 8th Grades School9th, 10th, 11th and 12th grades)]: The document was prepared by the Ministry of National Education in 2018. The first and second research questions were answered through this document.

2. The third research question was answered through the four English language course books which were prepared according to the new ELTP and published by the Ministry of National Education to use in lower secondary or middle schools in Turkey. These books are:

a) Ortaokul ve İmam Hatip Ortaokulu İngilizce 5 Ders Kitabı [Middle School and Religious Middle School English 5 Course Book] (Yalçın, Genç, Orhon, \& Şahin, 2019);

b) Ortaokul ve İmam Hatip Ortaokulu İngilizce 6 Ders Kitab1 [Middle School and Religious Middle School English 6 Course Book] (Demircan, Akıskalı, Berket, \& Günay, 2019);

c) Ortaokul ve İmam Hatip Ortaokulu İngilizce 7 Ders Kitabı [Middle School and Religious Middle School English 7 Course Book] (Aykanat Erdem, Balc1, \& Duran Özdil, 2019); and

d) Mastermind Ortaokul ve İmam Hatip Ortaokulu İngilizce 8 Ders Kitab1 [Mastermind Middle School and Religious Middle School English 8 Course Book] (İlter, İzgi, Çavuşer Özdemir, Türkeri Yeter, \& Çavuşer Yünlü, 2019).

\subsection{Data analysis}

Documentation analysis was used to analyze the documents. The researcher followed the framework that Yıldırım and Şimşek (2013) suggested to use in making documentation analysis. The framework is showed in the figure below. 


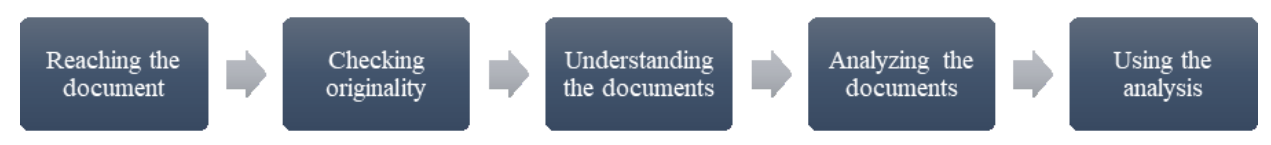

Figure 1. Steps of documentation analysis offered by Yıldırım and Şimşek (2013).

The researcher reached the printed versions of the 5th, 6th, 7th, and 8th-grade EL courses published by the Ministry of National Education in 2019 and the online version of the part of the new ELTP for lower secondary schools on its official website in relation to the research purpose and research questions of the present study. Therefore, all of the documents were considered to be original. Besides, the documents were understandable because the researcher was an English language teacher with 10-year teaching experience and taught different English courses for general, academic, specific, and occupational purposes. In those courses, he used the curricula and syllabi prepared by the departments and sometimes prepared and developed his syllabi during this time period. He also attended curriculum and/or syllabus evaluation meetings and received curriculum and syllabus evaluation courses. These experiences enabled him to understand the documents. A documentation analysis protocol was developed and used according to the literature to analyze the documents in the fourth step and to explain the research questions in the fifth step.

\subsection{Trustworthiness}

Triangulation can make a qualitative study trustworthy because according to Creswell and Poth (2018), it helps to corroborate the evidence through multiple data collection tools. Therefore, the present study used triangulation because the findings obtained from the documentation analysis of the new ELTP (which was the main data collection tool) were supported by the documentation analysis of the course books prepared and published by the Ministry of National Education. Besides, Creswell and Poth (2018) stated that providing a rich and thick description can also make a qualitative study trustworthy because a rich and thick description indicates that the qualitative analysis reflects only what is found out in the research (Lincoln \& Guba, 1985). Thus, the rich and thick description of the data was used to support the qualitative analysis in the present study.

\section{Results}

The findings of the study were presented according to the research questions.

\subsection{Theme(s) related to nature in the new ELTP for lower secondary school}

The part of the ELTP for lower secondary school includes ten themes. The themes in each grade are presented in the table below. 
Table 1

Themes in the syllabi of the 5th, 6th, 7th, an 8th grades

\begin{tabular}{|c|c|c|c|c|}
\hline Themes & $5^{\text {th }}$ Grade & $6^{\text {th }}$ Grade & $7^{\text {th }}$ Grade & $8^{\text {th }}$ Grade \\
\hline 1 & Hello & Life & $\begin{array}{l}\text { Appearance and } \\
\text { personality }\end{array}$ & Friendship \\
\hline 2 & My town & Yummy breakfast & Sports & Teen life \\
\hline 3 & $\begin{array}{l}\text { Games and } \\
\text { hobbies }\end{array}$ & Downtown & Biographies & In the kitchen \\
\hline 4 & My daily life & $\begin{array}{l}\text { Weather and } \\
\text { emotions }\end{array}$ & Wild animals & On the phone \\
\hline 5 & Health & At the fair & Television & The Internet \\
\hline 6 & Movies & Occupations & Celebrations & Adventures \\
\hline 7 & Party time & Holidays & Dreams & Tourism \\
\hline 8 & Fitness & Bookworms & Public buildings & Chores \\
\hline 9 & $\begin{array}{l}\text { The animal } \\
\text { shelter }\end{array}$ & Saving the planet & Environment & Science \\
\hline 10 & Festivals & Democracy & Planets & Natural forces \\
\hline
\end{tabular}

All of the syllabi have themes directly related to the nature. There is one theme in the 5th-grade syllabus. It is theme 9 (the animal shelter). Themes 4 (weather and emotions) and 9 (saving the planet) are nature-related themes in the 6thgrade syllabus. Like the 6th-grade syllabus, the 7th-grade syllabus has two nature-related themes. They are themes 4 (wild animals) and 9 (environment). Like the 5th-grade syllabus, there is one theme related to the nature in the 8thgrade syllabus. It is theme 10 (natural forces).

\subsection{Expectations from the students to achieve in the nature-related theme(s) in terms of language skills and learning objectives}

The new ELTP has focused on listening, speaking, and reading in 5th-grade syllabus in terms of language skills and learning outcomes. A 5th-grade EL student is expected to talk about the actions of animals and people. He/she can also understand the descriptions about animals' and people's actions in short, simple, written and oral texts.

In the 6th, 7th, and 8th-grade syllabi of the new ELTP, the focus of language skills and learning outcomes is on listening, speaking, reading, and writing. Speaking is categorized as spoken interaction and production. In theme 4 of the 6th-grade EL course book, an EL student can listen for specific information in brief texts related to weather conditions and emotions. He/she can ask people questions about the weather and speak to them about the weather, weather 


\section{Acta Educationis Generalis \\ Volume 10, 2020, Issue 3}

conditions, and emotions. In relation to these goals, he/she is expected to read and understand simple and short texts about the same topics in reading. In theme 9, he/she can identify appropriate attitudes toward energy saving and environmental protection in simple oral texts. He/she can realize suggestions to protect the environment in listening. He/she can speak to other students about the protection of the environment by making suggestions. He/she is expected to read and understand the passages about the protection of the environment in addition to writing about how to protect the environment.

According to the 7th-grade syllabus, an EL student is expected to find out wild animals' names in simple and short oral texts in theme 4. It is also expected from him/her to ask questions to people about wild animals and their characteristics in speaking. He/she can also recognize wild animals' names in reading texts and describe wildlife by writing about it. In theme 9 , he/she can listen to simple texts and understand the commonly used phrases and vocabulary about the environment. In reading, it is expected from him/her to read for specific information in passages related to the environment. In writing, he/she is supposed to compose brief and simple messages related to the environment.

In the 8th-grade syllabus, an EL student is supposed to listen for the main details of TV news that focuses on natural forces and disasters. In speaking, he/she can express his/her predictions about the future of the Earth and support them by talking about the reasons and results of his/her predictions. In reading, he/she can read for specific information in passages about natural forces and disasters. $\mathrm{He} / \mathrm{she}$ is expected to write a short paragraph about what causes natural forces and disasters and how they influence people and the environment.

\subsection{Conceptualization and practice of the nature-related theme(s) by the 5th,} 6th, 7th, and 8th-grade EL course books

In the 5th-grade EL course book, theme 9 starts by a talking activity about animals and pets. Elephant, monkey, bee, dog, cat, horse, duck, snake, lion, wolf, parrot, and cow are the target words in the theme (Yalçın et al., 2019, p. 144). The listening activities focus on a) a dialogue between Sally and her mom who talk about the actions of different animals and people in the town animal shelter; and b) simple oral texts about the actions of Susan, Betty, Mike, and Jimmy in animal-related places. The four reading texts in the course book give information about a) what Tim and his family are doing in their farm; b) what Steve and his parents are doing in their village; c) what Mark, Paul, Mary, Linda, and Lisa are talking to one of their parents about environment-related actions; and d) what Rose and her vet dad are talking about an injured puppy. The speaking part of the theme is contextualized as people and animals' actions in nature-related pictures. It requires talking about what people and/or animals are doing in the pictures. During the whole theme, human actions in the environment such as collecting eggs, watering plants, and feeding animals are constantly mentioned and practiced in the exercises. 


\section{Acta Educationis Generalis \\ Volume 10, 2020, Issue 3}

In the 6th-grade EL course book, theme 4 focuses on weather conditions and people's feelings in different weather conditions. Target words include the words used to explain a) weather conditions such as sunny, stormy, and freezing; and b) feelings including moody, scared, and anxious (Demircan et al., 2019, pp. $66,67,69)$. The listening activities require identifying which weather conditions are mentioned and finding out how Alan and Barbara feel in different weather conditions. Besides, there are two reading texts. The first one is a postcard from Paola to Cemre about different weather conditions and her feelings in these weather conditions in Rome. The second reading passage is a weather forecast where students learn weather conditions, temperatures, and people's feelings in different parts of a country. The assessment part asks students to prepare a poster where weather conditions, temperatures, and people's feelings are compared in two cities.

Theme 9 in the 6th-grade EL course book deals with different types of pollution and solutions to them. Target words can be categorized as good and bad for the environment. The good include recycling batteries, papers, and plastic, turning off the lights and the tap, and saving energy, while harming animals, cutting down trees, and throwing rubbish around are among the bad ones (Demircan et al., 2019, pp. 159-173). Students are asked to talk about several environmental problems such as cutting down trees shown in the pictures and described in the exercises. They need to find out and offer solutions to these problems to save the environment in these activities. There are two reading texts in theme 9. The first one is about the Mother Earth that tells how human activities have changed her by creating different types of pollution such as water pollution and what should be done to prevent more pollution. The other one is a dialogue between Ali and his parents who remind him of what he should do to save the environment before he leaves home. The oral text is based on a dialogue among Alex, Julia, Steve, and their teacher who talk about human activities as the reasons for environmental problems (water pollution, traffic jam, and deforestation) and solutions to such problems. The writing section wants students to write slogans for the protection of the environment. The project part asks them to use waste materials to make a useful object.

In the 7th-grade EL book, theme 4 is contextualized according to endangered and extinct wild animals. It begins by talking about some wild animals and whey they are dangerous. Target words are elephant, lion, bear, zebra, crocodile, tiger, snake, eagle, monkey, rhino, kangaroo, dolphin, whale, shark, octopus, mammals, reptiles, carnivores, and herbivores (Aykanat et al., 2019, pp. 48-49). The reading section includes a dialogue between Tom and Leo about one extinct animal (saber-toothed tiger), a living animal (Tiger), and their characteristics. The other reading text is based on three volunteers of the World Wide Fund for Wildlife who informs about three endangered animals (the Mediterranean monk seals, Asian elephants, and giant pandas), their characteristics, human activities causing them to be endangered, and solutions to survive them. The listening 


\section{Acta Educationis Generalis \\ Volume 10, 2020, Issue 3}

section includes an oral text about wild animals and why three of animal species (some kinds of sharks, owls, and polar bears) are endangered. The speaking section requires talking about extinct and endangered animals, their characteristics, the reasons for their being extinct and endangered, and the ways to help endangered animals survive. The writing section is based on preparing a brochure about giraffes, their characteristics, the effects of human activities on them, and the ways to survive them. The project part asks for presenting the characteristics of and the ways to protect two wild animals in a poster.

Theme 9 in the 7th-grade EL course book studies the environment in terms of types of pollution and solutions to deal with them. It starts by talking about types of pollution and the solutions to them. Target words are air pollution, water pollution, global warming, deforestation, pesticides, nuclear waste, rainforest, solar energy, wind energy, recycle, an eco-friendly bag, and plant a tree (Aykanat et al., 2019, p. 108). The reading section includes a dialogue about global warming and two reading texts about deforestation and wasting energy. They explain how human activities have caused these environmental problems, how they affect the environment and people, and how they can be dealt with. The speaking section asks students to talk about different environmental problems such as the extinction of animals and global warming, solutions to these problems, and an environmental protection campaign that they will make. They are expected to give explanations and reasons for the solutions they offer. In the listening section, there is a dialogue between Emily and her father who talk about making a campaign "Plant your own tree" to prevent air pollution. In the writing section, students are asked to write a paragraph about two environmental issues such as noise pollution and suggestions to prevent them. The poster part requires offering solutions to protect the nature by giving explanations and reasons.

Theme 10 in the 8th-grade EL book considers natural forces as natural and human-initiated disasters. It begins by talking about natural forces in different places. Target words are volcano, earthquake, tornado, drought, tsunami, hurricane, erosion, deforestation, animal and plan extinction, global warming, and avalanche (Ilter et al., 2019, pp. 120-130). Students are asked to talk about natural and human-initiated forces and disasters including global warming and destructive floods by explaining their reasons, their effects on the environment and human life, and some solutions to them. Besides, they are expected to determine and talk about how eco-friendly they are. There are three reading passages: a blog writing about global warming, a dialogue between Aslı and Betty about the Amazon forests, and a news report about the irresponsible use of natural resources. They explain how human activities have caused these problems, how these problems have influenced the environment and people, and/or how these problems can be dealt with. The listening section gives information about the avalanche in Artvin (a Turkish city) and its effects on people and the environment in the city. The writing section requires writing a 


\section{Acta Educationis Generalis \\ Volume 10, 2020, Issue 3}

paragraph about a natural force in terms of its reasons, effects on life, and solutions.

\section{Discussion}

Theme 9 is related to the animal shelter in the 5 th-grade syllabus. It can indicate EL students the interaction between human beings and animals through the reading passages about Tim and his family and Steve and his parents because the passages explain the lives of those people and their actions such as milking the cows and watering plants in a farm and village. Other reading texts and the listening texts can inform students about the positive effects of human activities on animals since these texts mention positive human activities such as adopting an animal and feeding an animal for animals. Therefore, these texts can raise EL students' awareness of the interdependency of human beings and animals and their effects on each other. This awareness is promoted by the speaking activities. As a result, the contextualization and practice of theme 9 in the course book can help students to achieve what is expected from them and can make the 5th-grade syllabus ecological to some extent.

Theme 4 of the 6th-grade EL syllabus is based on weather conditions and people's emotions in different weather conditions. It can enable EL students to understand the effect of the nature on people through the reading, listening, speaking, writing, and assessment sections which show how people's emotions change in different weather conditions. The contextualization and practice of the theme are aligned with the course objectives tightly. As a result, theme 4 can help raise students' awareness of how the nature can affect people's lives including their emotions.

Theme 9 in the 6th-grade EL syllabus is about saving the planet. Unlike theme 4 which shows how the nature can affect people, theme 9 can indicate EL students how people can affect the nature negatively through their activities. The reading and oral texts explain how human activities have caused several environmental problems and how such problems can be dealt with and overcome by human beings. Similarly, the speaking parts emphasize the responsibility of people for saving the world by making students talk about environmental issues and offer solutions to them for making the world better. The project part can also help them understand that they can help the environment by reusing their waste materials. These parts, therefore, can inform students about the close relationship between people and the environment, the negative effects of human activities on the environment, and the responsibility of people for the environment. The contextualization and practice of theme 9 are aligned with the course objectives well. Consequently, theme 9 can contribute to raising students' awareness of the negative effects of human activities on the environment and their responsibility for saving it. It can enable them to practice their awareness by producing something from waste material. 


\section{Acta Educationis Generalis \\ Volume 10, 2020, Issue 3}

Theme 4 in the 7th-grade syllabus demonstrates the negative and destructive effects of human activities on wild animals to EL students. The main focus of theme 4 is on wild animals, especially the ones which have become extinct or endangered because of human activities such as overhunting. Its reading, listening, speaking, and writing parts can help students understand this. Besides, the theme also indicates them that people can do things to save wild animals especially through the writing and project sections. The contextualization and practice of theme 4 seem to enable students to meet its objectives. Consequently, theme 4 can show the destructive influence of people on wild animals to students and encourage them to find out solutions to this problem, so it can raise students' awareness.

Theme 9 approaches the environment in terms of how human beings have caused different types of pollution and what they should do to deal with these pollution types. Accordingly, the reading section informs students about these two points as well as the negative effects of environmental problems on people and the environment. The speaking section supports the reading section because students are asked to talk about different environmental problems and make suggestions to deal with them by explaining their reasons for their suggestions. Like the speaking section, they are asked to do similar things in the writing and poster sections, so these two sections can encourage the active participation of students in the environmental issues more. Also, the listening and speaking activities about organizing an environmental protection campaign can reinforce the fact that people can change what they have done to the environment. The objectives of theme 9 can be met by EL students through this contextualization and practice of the theme. Therefore, theme 9 can enable them to be more sensitive to the environment and encourage them to take actions for the protection of the environment.

Like the themes of the 7th-grade syllabus, theme 10 in the 8th-grade syllabus explains students how human activities have caused natural disasters, how natural disasters have influenced people's lives and the environment negatively to a big extent, and how people can reverse what they have done to the environment. The reading section supports this by informing students about the possible answers to these questions. The listening text emphasizes that what happened in Artvin was the result of human activities. In relation to the reading and listening sections, the speaking section also promotes the fact that human activities may be harmful to the environment due to their negative effects on the environment, but people can change what they have created in a positive way. The section can do this by having students talk about different natural disasters, their reasons (generally related to human activities), their effects on people's lives and the environment, and the solutions to the disasters. The writing section also promotes this fact by following a similar procedure. Due to the contextualization and practice of the theme, students can meet the objectives of 


\section{Acta Educationis Generalis \\ Volume 10, 2020, Issue 3}

the theme. Consequently, theme 10 can be considered as effective in helping students to raise their awareness and become more sensitive to the environment. Themes 9 in the 6th grade, 4 and 9 in the 7 th grade, and 10 in the 8th grade focus on the environmental issues considered as the indicators of the Anthropocene (Crutzen, 2006a, 2006b; Lewis \& Maslin, 2015; Steffen et al., 2013; Zalasiewicz et al., 2010; Zalasiewicz et al., 2011). The contents of these themes can provide EL students with a clear and understandable cause-effect relationship between human activities and the environmental issues, so students can understand that human activities have caused serious problems in the environment as Sterling (2017) stated. Besides, the themes can enable them to realize that people have the power to change the nature through their activities as mentioned by Crutzen (2006a, 2006b), Lewis and Maslin (2015), Steffen et al. (2013), and Zalasiewicz et al. (2011). Besides, the themes inform students that human can do several things to reverse the negative effects of human activities on the environment, which can teach students how they can live with the environment in balance because ecological education aims to show this to students (Somerville, 2017; Taylor, 2017). Besides, theme 9 in the 5th grade shows how people can contribute to the environment through their actions because it includes human actions such as feeding animals, watering the plants, examining animals, and donating money for animals that can be considered beneficial to the environment. Also, theme 4 in the 6th grade supports the fact that the environment can also affect people. Therefore, all of these themes in the new ELTP for lower secondary school can enable EL students to realize, find out, and understand that people are part of the nature, that the more-than-human world constitutes people, and that people are dependent on the more-than-human world (Somerville, 2017). As a result, the new ELTP for lower secondary school in Turkey can respond to the trans-disciplinary call made by Carstens (2016), Leinfelder (2013), and Somerville (2017) to some extent. Thus, EL students can contribute to the sustainability of the environment for the future as Crutzen (2006b) emphasized.

\section{Conclusions}

The Anthropocene is considered a big problem for people due to the destructive effects of human activities on the environment which reduce the sustainability of the environment for the future. One way to deal with what the Anthropocene has revealed is education, and there is a trans-disciplinary call for this. The present study has aimed to evaluate the new ELTP for lower secondary school in Turkey with this purpose. The findings of the study have indicated that the new ELTP has 6 themes related to the nature and can enable EL students to raise their awareness of the fact that human activities have affected the nature negatively and that people can do something to change this situation.

This study can be useful for EL teachers, course book writers, and curriculum developers because it provides them with the information about what the 


\section{Acta Educationis Generalis \\ Volume 10, 2020, Issue 3}

Anthropocene means and how they can evaluate their curricula and course books with an Anthropocentric perspective. Such evaluation can show the strengths and weaknesses of their curricula and course books in terms of the Anthropocene, so they can work on their weaknesses, compensate for the weaknesses, and contribute to the sustainable future of the world by raising their students' awareness.

For the same research purpose, future research can be made to evaluate the whole English language teaching curriculum and the syllabus of specific grades in different research contexts by following the research methodology of the present study. Also, future research can evaluate EL course books by following the methodology of the present study for the same research purpose. Such evaluation can be integrated with EL material development research to make the curriculum, syllabus, and course books more ecological.

\section{References}

Aksoy, E. (2020). Evaluation of the 2017 updated secondary school English curriculum of Turkey by means of theory-practice link. Turkish Journal of Education, 9(1), 1-21.

Aktı Aslan, S., \& İzci, E. (2017). Evaluation of secondary school English teaching program according to the remarks of teachers with context, input, process and product (CIPP) model. Inönü University Journal of the Faculty of Education, 18(2), 33-44.

Ar1, A. (2014). Teacher opinions about evaluation of $6^{\text {th }}$ grade English lesson curriculum in primary schools. Journal of Theoretical Educational Science, 7(2), 172-194.

Aykanat Erdem, A., Balc1, T., \& Duran Özdil, K. (2019). Ortaokul ve imam hatip ortaokulu Ingilizce 7 ders kitabı. Ankara: Milli Eğitim Bakanlığı Yayınlar1.

Cartens, D. (2016). The Anthropocene crisis and higher education: A fundamental shift. South African Journal of Higher Education, 30(3), 255273.

Creswell, J. W. (2014). Research Design: Qualitative, Quantitative, and Mixed Methods Approaches (4th ed.). Thousand Oaks: Sage Publications Inc.

Creswell, J. W., \& Poth, C. N. (2018). Qualitative Inquiry \& Research Design: Choosing among Five Approaches (4th ed.). Thousand Oaks: Sage Publications Inc.

Crutzen, P. J. (2006a). The "Anthropocene". In E. Ehlers, \& T. Krafft (Eds.), Earth System Science in the Anthropocene (pp. 13-18). Springer.

Crutzen, P. J. (2006b). The Anthropocene: The Current Human-Dominated Geological Era. Retrieved from http://www.pas.va/content/dam/accademia/ pdf/acta18/acta18-crutzen.pdf 
Demircan, F., Akıskalı, G., Berket, A., \& Günay, F. (2019). Ortaokul ve imam hatip ortaokulu Ingilizce 6 ders kitabı. Ankara: Milli Eğitim Bakanlığı Yayınları.

Demirtaş, Z., \& Erdem, S. (2015). 5. sınıf İngilizce dersi öğretim programı: Güncellenen programın bir önceki programla karşılaştırılması ve programa ilişkin öğretmen görüşleri. Sakarya University Journal of Education, 5(2), 55-80.

Dinçer, A., \& Koç, H. K. (2020). The implementation of an intensive English language program in the fifth grade in Turkey: A qualitative evaluation. Journal of Theoretical Educational Research, 13(1), 25-43.

Dinçer, B., \& Saracaloğlu, A. S. (2017). 7. sınıf İngilizce öğretim programının Stufflebeam'in bağlam-girdi-süreç-ürün (Cipp) modeline göre değerlendirilmesi. Qualitative Studies (NWSAQS), 12(2), 1-24.

Gilbert, J. (2016). Transforming science education for the Anthropocene - is it possible? Research in Science Education, 46, 187-201.

Goulah, J. (2018). Religion, "the religious," and language education into the Anthropocene: A response to Huamei Han's "Studying religion and language teaching and learning: Building a subfield." The Modern Language Journal, 102, 451-455.

Gray, D., \& Colucci-Gray, L. (2014). Globalisation and the Anthropocene: The reconfiguration of science education for a sustainable future. Sisyphus Journal of Education, 2(3), 14-31.

İlter, B., İzgi, İ., Çavuşer Özdemir, E., Türkeri Yeter, A., \& Çavuşer Yünlü, Z. T. (2019). Mastermind ortaokul ve imam hatip ortaokulu Ingilizce 8 ders kitabı. Ankara: Milli Eğitim Bakanlığı Yayınları.

Kozikoğlu, İ. (2014). Ortaokul 7. sınıf İngilizce öğretim programının değerlendirilmesi. Abant İzzet Baysal Üniversitesi Eğitim Fakültesi Dergisi, 14(1), 361-375.

Leinfelder, R. (2013). Anthropocene: Envisioning the future age of humans. RCC Perspectives, 3, 9-28.

Lewis, S. L., \& Maslin, M. A. (2015). Defining the Anthropocene. Nature, 519, 171-180.

Lincoln, Y. S., \& Guba, E. G. (1985). Naturalistic inquiry. Newbury Park, CA: Sage Publications.

Mahaffy, P. G. (2014). Telling time: Chemistry education in the Anthropocene epoch. Journal of Chemical Education, 91, 463-465.

Milli Eğitim Bakanlığı. (2018). Ingilizce dersi ögretim programı (ilkokul ve ortaokul 1, 2, 3, 4, 5, 6, 7 ve 8. sinfflar). Retrieved from http://mufredat. meb.gov.tr/Dosyalar/201812411191321-\%C4\%B0NG\%C4\%B0L\%C4\%B0ZCE $\% 20 \%$ C3\%96\%C4\%9ERET\%C4\%B0M\%20PROGRAMI\%20Klas\%C3\%B6r\%C3 $\%$ BC.pdf 


\section{Acta Educationis Generalis \\ Volume 10, 2020, Issue 3}

Ordem, E., \& Ulum, Ö. G. (2020). Gender issues in English language teaching: Views from Turkey. Acta Educationis Generalis, 10(1), 25-39. https://doi.org/10.2478/atd-2020-0002

Pawson, E. (2015). What sort of geographical education for the Anthropocene? Geographical Research, 53(3), 306-312.

Prádanos, L. I. (2015). La enseñanza del español en la era del antropoceno: Hacia la integración de la sostenibilidad en las clases de español como lengua extranjera. Hispania, 98(2), 333-345.

Somerville, M. (2017). The Anthropocene's call to educational research. In K. Malone, S. Truong, \& T. Gray (Eds.), Reimagining sustainability in precarious times (pp. 17-28). Springer.

Steffen, W., Grinevald, J., Crutzen, P., \& McNeill, J. (2011). The Anthropocene: Conceptual and historical perspectives. Philosophical Transactions of the Royal Society A, 369, 842-867.

Sterling, S. (2017). Assuming the future: Repurposing education in a volatile age. In B. Jickling, \& S. Sterling (Eds.), Post-sustainability and environmental education (pp. 31-45). Palgrave.

Taylor, A. (2017). Beyond stewardship: Common world pedagogies for the Anthropocene. Environmental Eduction Research, 23(10), 1448-1461.

Wagler, R. (2011). The Anthropocene mass extinction: An emerging curriculum theme for science educators. The American Biology Teacher, 73(2), 78-83.

Yalçın, M., Genç, G., Orhon, N. Ö., \& Şahin, H. (2019). Ortaokul ve imam hatip ortaokulu İngilizce 5 ders kitabı. Ankara: Milli Eğitim Bakanlığı Yayınları.

Yıldırım, A., \& Şimşek, H. (2013). Sosyal bilimlerde nitel araştırma yöntemleri (9th ed.). Ankara: Seçkin Yayıncılık.

Yücel, E., Dimici, K., Yıldız, B., \& Bümen, N. T. (2017). Son 15 yılda yayımlanan ilk ve ortaöğretim İngilizce dersi öğretim programları üzerine bir analiz. Ege Eğitim Dergisi, 18(2), 702-737.

Zalasiewicz, J., Williams, M., Haywood, A., \& Ellis, M. (2011). The Anthropocene: A new epoch of geological time? Philosophical Transactions of the Royal Society A, 369, 835-841.

Zalasiewicz, J., Williams, M., Steffen, W., \& Crutzen, P. (2011). The new world of the Anthropocene. Environmental Science \& Technology, 44, 2228-2231. 